\title{
VOLUME XLVIII AUTHOR INDEX
}

Author

ADAMS, WILliam W.

Adleman, Leonard M., ESTES, DENNIS R. \& MCCURLEY, KEVIN S.

AtKinson, Kendall \& BOGOMOLNY, ALEX

AUZINGER, WINFRIED

BERRUT, JEAN-PAUL \& TRUMMER, MANFRED R.

BLECKSMITH, RICHARD, BRILLHART, JOHN \& GERST, IRVING

BOGOMOLNY, ALEX

BRILLHART, JOHN

BUChMANN, JOHANNES

BUCHMANN, JoHANNES \& Williams, H. C.

BUCK, NICHOLAS, SMITH, LONES, SPEARMAN, BLAIR K. \& WilliaMs, KENNETH S.

Buell, DuNCAN A.

CANTOR, David G.

Chui, C. K., JetTer, K. \& WARD, J. D.

COHEN, H. \&

LENSTRA, A. K.

COHEN, H. \&

MARTINET, J.

COHN, HARVEY \& DEUTSCH, JESSE

Criscuolo, Giuliana \& MASTROIANNI, GIUSEPPE

Crouzeix, M. \& THOMÉE, V.

CUSICK, T. W. \& SCHOENFELD, LOWELL

DEUTSCH, JESSE

ERICSSON, THOMAS
Title

Page

Characterizing Pseudoprimes for Third-Order Linear Recurrences . . . . . . . . . . . . . 1

Solving Bivariate Quadratic Congruences in Random Polynomial Time . . . . . . . . . . . . . 17

The Discrete Galerkin Method for Integral Equations . .

Defect Corrections for Multigrid Solutions of the Dirichlet Problem in General Domains . . . . . . . . . . .

Equivalence of Nyström's Method and Fourier Methods for the Numerical Solution of Fredholm Integral Equations

Parity Results for Certain Partition Functions and Identities Similar to Theta Function Identities . . . . . . . .

See: Atkinson, Kendall \& Bogomolny, Alex . .

See: BLECKSMITH, RICHARD, BRILLHART, JOHN \& GERST, IRVING . . . . . . . . . . .

The Computation of the Fundamental Unit of Totally Complex Quartic Orders . . . . . . . . . . . .

On Principal Ideal Testing in Totally Complex Quartic Fields and the Determination of Certain Cyclotomic Constants . . . . . . . . . . . . .

The Cyclotomic Numbers of Order Fifteen . . . . . . . .

Class Groups of Quadratic Fields. II . . . . . . . . . . . 85

Computing in the Jacobian of a Hyperelliptic Curve . . 95

Cardinal Interpolation by Multivariate Splines . . . . . . 711

Implementation of a New Primality Test $\ldots \ldots \ldots \ldots$

Class Groups of Number Fields: Numerical Heuristics . .

Application of Symbolic Manipulation to Hecke Transformations of Modular Forms in Two Variables . . . .

On the Convergence of an Interpolatory Product Rule for Evaluating Cauchy Principal Value Integrals . . . . . .

The Stability in $L_{p}$ and $W_{p}^{1}$ of the $L_{2}$-Projection onto Finite Element Function Spaces . . . . . . . . . .

A Table of Fundamental Pairs of Units in Totally Real Cubic Fields . . . . . . . . . . . . . . . . . 147

See: Cohn, Harvey \& Deutsch, Jesse . . . . . . . 139

See: NOUR-OMID, BAHRAM, PARLETT, BERESFORD N., ERICSSON, THOMAS \& Jensen, Paul S. . . . . . . 55

67

\section{(1)}

7
5

95

03


Author

Estes, Dennis R.

FAM, ADLY T.

Gartland, Eugene C., JR.

DE GEe, MAARTEN

GERST, IRVING

GIRSTMAIR, KURT

GLADWIN, C. J.

GoldBerg, MOSHE \& TADMOR, EITAN

GORDON, DANIEL, GRENIER, DOUglaS \& TERRAS, AUDREY

GRAS, MARIE-NICOLE

GRENIER, DOUGLAS

GUY, R. K., LACAMPAGNE, C. B. \& SElfRidge, J. L.

HAGSTROM, T. M. \& KELLER, H. B.

Jensen, Paul S.

JETTER, K.

JIA, RONG-QING

JING, ZHONGQI \&

FAM, ADLY T.

JOHNSEN, BEN \&

STRAUME, ELDAR

KELLER, H. B.

KISS, PÉTER \&

PHONG, BUI MINH

KOBLITZ, NEAL

KUMAR, SUNIL \&

SLOAN, IAN H.

LACAMPAGNE, C. B.

LEHMER, D. H. \&

LEHMER, EMMA

LEHMER, EMMA

LENSTRA, A. K.

LENSTRA, H. W., JR. \&

SCHOOF, R. J.

MARTINET, J.

MASTROIANNI, GiUSEPPE
Title

Page

See: Adleman, Leonard M., Estes, Dennis R. \& MCCURLEY, KeVIN S. . . . . . . . . . . . . . 17

See: JING, ZHONGQI \& FAM, ADLY T. . . . . . . . . . 691

Uniform High-Order Difference Schemes for a Singularly Perturbed Two-Point Boundary Value Problem . . . .

Linear Multistep Methods for Functional Differential Equations . . . . . . . . . . . . .

See: BlECKSMITH, RICHARD, BRILlHART, JOHN \& GERST, IRVING . . . . . . . . . . . .

On Invariant Polynomials and Their Application in Field Theory . . . . . . . . . . . . . .

An Algorithm for the Construction of Optimal Methods for the Numerical Solution of Volterra Integral Equations of the First Kind . . . . . . . . . . . . .

Convenient Stability Criteria for Difference Approximations of Hyperbolic Initial-Boundary Value Problems. II . .

Hecke Operators and the Fundamental Domain for $\operatorname{SL}(3, \mathbf{Z}) \ldots \ldots \ldots \ldots \ldots \ldots \ldots$

Special Units in Real Cyclic Sextic Fields . . . . . . . .

See: Gordon, Daniel, Grenier, Douglas \&

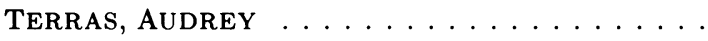

Primes at a Glance . . . . . . . . . . . . . . 183

Asymptotic Boundary Conditions and Numerical Methods for Nonlinear Elliptic Problems on Unbounded Domains

See: NoUR-OMID, BAHRAM, PARLETT, BERESFORd N., Ericsson, Thomas \& Jensen, Paul S. . . . . . .

See: ChUi, C. K., JetTer, K. \& WARD, J. D. . . . . .

$L_{\infty}$-Boundedness of $L_{2}$-Projections on Splines for a Multiple Geometric Mesh . . . . . . . . . . . . .

An Algorithm for Computing Continuous Chebyshev Approximations . . . . . . . . . . . .

Counting Binary Matrices with Given Row and Column Sums . . . . . . . . . . . . . . 737

See: Hagstrom, T. M. \& Keller, H. B. . . . . . . 449

On a Problem of A. Rotkiewicz . . . . . . . . . . 751

Elliptic Curve Cryptosystems . . . . . . . . . . . . . 203

A New Collocation-Type Method for Hammerstein Integral

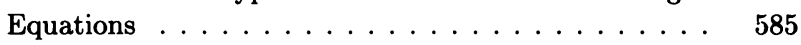

See: GUY, R. K., LACAMPagne, C. B. \& Selfridge, J. L. . . . . . . . . . . . . . . . . . . . . . . . 183

Cyclotomic Resultants . . . . . . . . . . . . . . 211

See: LehMER, D. H. \& LeHMER, EMmA . . . . . . . 211

See: Cohen, H. \& Lenstra, A. K. . . . . . . . . . 103

Primitive Normal Bases for Finite Fields . . . . . . . 217

See: Cohen, H. \& Martinet, J. . . . . . . . . . . 123

See: Criscuolo, GiUliana \& Mastroianni, GIUSEPPE . . . . . . . . . . . . . . . 725 
Author

MATTHEIJ, R. M. M.

MCCURLEY, KeVIN S.

MOLLIN, R. A.

MONTgomery, Peter L.

MOODY, R. V. \&

PATERA, J.

Neubauer, A.

NEWMAN, MORRIS \& THOMPSON, ROBERT C.

NOUR-OMID, BAHRAM, PARLETT, BERESFORD N., ERICSSON, THOMAS \& JENSEN, PAUL S.

ODLYZKO, A. M.

PARLETt, BERESFORD N.

PAtera, J.

PhONG, BUI MINH

POHST, M.

POMERANCE, CARL

te Riele, Herman J. J.

SAAD, YOUCEF

SARANEN, JUKKA

SCHOENFELD, LOWELL

SCHOOF, R. J.

SELFRIDGE, J. L.

SEYSEN, MARTIN

Silverman, ROBERT D.

SLOAN, IAN H.

SMITH, LONES

SPEARMAN, Blair K.

STRAUME, ELDAR

TADMOR, EITAN

TANNER, JONATHAN W. \& WAGSTAFF, SAMUEL S., JR.

Terras, AUdrey
Title

Page

On the Computation of Solutions of Boundary Value Problems on Infinite Intervals . . . . . . . . . . .

See: Adleman, Leonard M., Estes, Dennis R. \& MCCuRley, Kevin S. . . . . . . . . . . . . .

Class Numbers of Quadratic Fields Determined by Solvability of Diophantine Equations . . . . . . . . . . . .

Speeding the Pollard and Elliptic Curve Methods of Factorization ..............

Computation of Character Decompositions of Class Functions on Compact Semisimple Lie Groups . . . . . . . .

Finite-Dimensional Approximation of Constrained Tikhonov-Regularized Solutions of Ill-Posed Linear Operator Equations . . . . . . . . . . . . . . .

Numerical Values of Goldberg's Coefficients in the Series for $\log \left(e^{x} e^{y}\right) \ldots \ldots \ldots \ldots \ldots \ldots$

How to Implement the Spectral Transformation . . . . . .

663

On the Distribution of Spacings Between Zeros of the Zeta Function . . . . . . . . . . . . . .

See: Nour-OMid BAHRAM, PARLETt, BerESFord N., ERICSSON, Thomas \& Jensen, PaUl S. . . . . . . 663

See: Moody, R. V. \& Patera, J. . . . . . . . . . . 799

See: KISS, PÉter \& PHONG, BUI Minh … . . . 751

On Computing Isomorphisms of Equation Orders . . . . 309

Very Short Primality Proofs . . . . . . . . . . . . . . 315

On the Sign of the Difference $\pi(x)-\operatorname{li}(x) \ldots \ldots \ldots . .323$

On the Lanczos Method for Solving Symmetric Linear Systems with Several Right-Hand Sides . . . . . . . .

Local Error Estimates for Some Petrov-Galerkin Methods Applied to Strongly Elliptic Equations on Curves . . . 485

See: Cusick, T. W. \& SChoenfeld, LOWEll . . . . 147

See: Lenstra, H. W., JR. \& Schoof, R. J. . . . . . . 217

See: GuY, R. K., Lacampagne, C. B. \& Selfridge, J. L. . . . . . . . . . . . . . . . . . . . . 183

A Probabilistic Factorization Algorithm with Quadratic Forms of Negative Discriminant . . . . . . . . $\quad 757$

The Multiple Polynomial Quadratic Sieve . . . . . . . . . 329

See: KUMAR, SUnil \& Sloan, IAN H. . . . . . . . . . 585

See: BUCK, Nicholas, SMith, LONes, Spearman, Blair K. \& Williams, KenNeTH S. . . . . . . . 67

See: BuCK, Nicholas, Smith, Lones, SPearman, Blair K. \& Williams, KenNeth S. . . . . . . . 67

See: Johnsen, Ben \& Straume, Eldar $\ldots \ldots \ldots .737$

See: Goldberg, MOSHE \& TAdMor, Eitan . . . . . 503

New Congruences for the Bernoulli Numbers . . . . . . . 341

See: Gordon, DANIEL, GRENIER, DOUglaS \& TERRAS, AUDREY 
Author

Title

Page

ThOMPSON, ROBERT C. See: NeWMAN, MORRIS \& ThOMPSON, ROBERT C. . $\quad 265$

THOMÉE, V.

See: Crouzeix, M. \& THomée, V. . . . . . . . . 521

TRUMMER, MANFRED R.

See: Berrut, Jean-Paul \& Trummer, Manfred R. 617

TSCHÖPE, HEINZ M. \&

Computation of the Néron-Tate Height on Elliptic Curves

351

See: TANNER, JONATHAN W. \& WAgStafF, SAMUEL S., JR. . . . . . . . . . . . . . . . . . . 341

WAGSTAFF, SAMUEL S., JR.

WARD, J. D.

See: ChUi, C. K., JetTeR, K. \& WARD, J. D. . . . . . 711

WASHINGTON, LAWRENCE C.

Williams, H. C.

Class Numbers of the Simplest Cubic Fields . . . . . . . 371

Williams, H. C.

Williams, H. C. \&

WUNDERLICH, M. C.

WILLIAMS, KENNETH S.

WUNDERLICH, M. C.

ZAGIER, DON

Effective Primality Tests for Some Integers of the Forms $A 5^{n}-1$ and $A 7^{n}-1 \ldots \ldots \ldots \ldots \ldots \ldots \ldots$

See: Buchmann, Johannes \& Williams, H. C. . . 55

On the Parallel Generation of the Residues for the Continued Fraction Factoring Algorithm . . . . . . . . 405

See: BuCK, Nicholas, SMith, LONES, SPEARMAN, Blair K. \& Williams, KenNeth S. . . . . . . . 67

See: Williams, H. C. \& Wunderlich, M. C. . . . . 405

Large Integral Points on Elliptic Curves . . . . . . . . 425

ZIMMER, HORST G.

See: TSCHÖPE, HEINZ M. \& ZimMER, HoRst G. . . . .

351

\section{STATEMENT OF OWNERSHIP AND MANAGEMENT}

Mathematics of Computation is published quarterly in January, April, July, and October each year by the American Mathematical Society. The Office of Publication and the General Business Office are located at 201 Charles Street, Providence, Rhode Island 02904. The Publisher is the American Mathematical Society. The Managing Editor is Christine Lefian, American Mathematical Society, P.O. Box 6248, Providence, Rhode Island 02940. There are no bondholders, mortgagees or other security holders. EXTENT AND NATURE OF CIRCULATION. Average number of copies of each issue during the preceding twelve months: total number of copies printed: 2,450; sales through dealers and carriers, street vendors and counter sales: 235; paid mail subscriptions: 1,728 ; total paid circulation: 1,963 ; samples, complimentary and other free copies: 75 ; total distribution: 2,038; office use, left over, unaccounted, spoiled after printing: 412; copies distributed to news agents but not sold: 0 ; total: 2,450. Actual number of copies of single issue published nearest to filing date: same as above.

\footnotetext{
Second class postage is paid at Providence, Rhode Island Volume 48, Number 178, April 1987, Pages 449-858

Copyright (c) 1987 by the American Mathematical Society

US ISSN 0025-5718
} 